\title{
Foreword
}

\section{By Robert Michael Pyle}

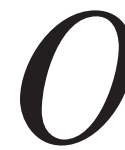

wls. The very word has excited me since I was a lad. Unlike the author of the extraordinary book you hold in your hands, I never caught, raised, or lived with owls. I encountered Hooty the Owl in Thornton Burgess's Bedtime Stories, loved The Owl and the Pussycat, and scoured the local public library's shelves for books on owls, just as I did for otters, seashells, and butterflies. Later I read accounts of people who lived with owls, ending up many years later with Jonathan Maslow's Owl Papers, Max Terman's Messages from an Owl, and Bernd Heinrich's One Man's Owl. And when I read the Harry Potter books, I thought by far the best thing in them was Harry's owl Hedwig, and all the other mail-courier owls. It's only too bad that as a kid conservationist, as I fancied myself, I was way too early for Carl Hiaasen's Hoot.

As much as I loved reading about owls as a boy, I was even more eager to encounter them in flesh and feather. There wasn't much chance in my postwar subdivision in Colorado. But it wasn't long before I escaped the ordered grid and barren young yards, wandering off to the High Line Canal, an old irrigation ditch on the edge of the actual countryside. There, one enchanted day, I watched as a great horned owl burst from an old magpie nest in a cottonwood-and all of a sudden, owls had become real.

Since that thrilling moment, I can remember the first sighting of every species of owl I've come to know in the wild: The first northern spotted owl, on its nest on a low big tree bough in Sequoia National Park. The first hawk owl, crowning a black spruce in the boundless taiga along the Alaska Highway. The first saw-whet, fishing the shoreline of a little lake near Olympia. The first great gray, early in the morning, in the Blue Mountains of northeastern Oregon, even bigger than I'd dreamed. The 
first pueo, gliding toward me like a plane with a face through mist on the shoulder of Mauna Kea. And certainly the first snowy, which until then had been a merely mythic bird-never there for me where everyone said it had been only the day before, or the hour. And then there it was at last, squinting against a cutting windborne snow on a frozen beach north of New Haven, Connecticut.

Actually, it was during my three years in New Haven that owls came to have one of their deeper significances for me. The owls I speak of neither flew nor hooted. They were ornamental owls—stone, terra cotta, wood, copper, and so on-decorating the campus of Yale University as a frequently repeating symbol of wisdom, learning, and all of the scholarly and courageous attributes of their familiar, Pallas Athena. When I arrived at Yale in the fall of 1974 for postgraduate studies, I got off to a rather slow start thanks to my own intimidation and a little uncertainty about my thesis plans. Once I began to notice the frequency of the owl motif in the college gothic architecture of the university and its various colleges, each one a campus within the larger campus, I began collecting them. At first this was chiefly a displacement activity, giving a little structure to counterbalance (or distract me from) my lack of confidence in being there. It wasn't long before the intimidation faded and my dissertation research gelled, so the reason for the displacement activity was gone. But by then I was so much enjoying the hunt that I continued owl spotting for the whole three years.

By the time I marched in Yale's 275th graduation exercise, I had tallied around seventy-five "species" of owls among its hallowed halls and graven walls, such as the great copper owl weathervane atop Sterling Library, the roundels of owlish gargoyles encircling the Law School's crocketed towers, and various carved owlets on door panels, reredos, and moldings. In the absence of actual owls they served well as a distraction from the heavy academic work. (Many years later, during a joint reading at Redlands College in southern California, my fellow writers and I looked up from our texts repeatedly to watch both barn and great-horned owls cruising past the open doors. Had Yale been like that, perhaps I never would have finished my studies!) The elegant blend of art and natural history represented by this indulgent pursuit remains for me nearly as memorable as Professor Charles Remington's inspired lectures on evolution, watching Meryl Streep's student performances in several Drama School productions, and that first real-life snowy, out on the frigid shore of Long Island Sound.

In the forty years since, how very many owls have graced my days and nights! Downy baby great horneds and barns in the basalt rimrock of eastern Washington. Banshee-voiced tawnies in the Somerset countryside. A bouncing, big-eyed bur- 
rowing owl peeking over a road-crest at dawn, where I'd been sleeping on the opposite verge, during a very slow hitchhike across the western United States. Short-eareds cruising the Skagit Flats in company with northern harriers and redtailed hawks and tens of thousands of snow geese. Particular pygmies and screeches in particular tree holes, faithfully present year after year. The barred owl of British Columbia whose shrill "who cooks for y'allll?" convinced a credulous young enthusiast that he had finally recorded Bigfoot. The still-life of a great horned owl, hunched in the crotch of a willow in a Wyoming winter landscape, that I mistook for a bobcat; and the one that cleaned out our hollow tree of its flying squirrels-one broad gray tail on the lawn every morning until they were gone-and then moved on. The barn owl that stooped at my cat, and the one I helped restore to its parents and siblings inside the gable of a very high barn, after rehab. The long-eareds, like small totems, lining the limbs of pines in a thick windbreak in the Columbia Basin, watched with Roger Tory Peterson on a bird convention field trip in 1971.

Another ornithological luminary along on that outing was Tony Angell. I had met Tony in Seattle in the 1960 s, one of a number of keen and talented naturalists who made the city so exciting and inspiring for a college kid like me. Our friendship went from there, and will soon span half a century. A few years into it, when I worked for The Nature Conservancy, Tony was chairman of the Washington chapter. By this time, it was already apparent that he was one of the premier sculptors, pen-and-ink artists, and writers anywhere working with birds and mammals. Tony's love of corvids and of owls and other raptors led to a long series of marvelous books. Maybe it was inevitable that he would one day write a book in which he laid out his lifelong passion for owls and what they have taught him. When I learned that such a book was on its way, I rejoiced. Here, I thought, will be the book to cap all the owl books I've loved before. And so it is.

The House of Owls is, simply, a delight for a strigiphile like me. But it will also delight any birder or naturalist, and all those who care about the living world and its more remarkable manifestations. The heart of the book for me is the title chapter, "The House of Owls," which relates the personal saga of a period when Tony and his family lived intimately with one dynasty of screech owls who shared their home habitat. The next chapter, "About Owls," gives the basic facts to understand how owls work, and how they fit into the broader context of life, and the third chapter describes how they have been accommodated in human culture. The remaining three chapters consist of detailed verbal portraits of all nineteen species of North 
American owls. The genius of this presentation lies not only in its comprehensiveness, and how we come away seeing the birds from all sides, but also in its shifting point of view. The first chapter is a deeply personal narrative that carries us not only further into the subject, but also further into the author than any of his earlier books have done. The other early chapters are largely factual and objective. And the comprehensive owl biographies are a masterful blend: each species is introduced through Tony's personal experience with it, and then its image is rounded out with fully researched, up-to-date information on its distinctive traits and lifeways. These accounts are nothing short of fascinating. The brilliant mix of personal and factual renders the whole compulsively readable.

There is one more category of readers for whom The House of Owls gives cause for huzzahs, and I count myself among them: Tony Angell fans. A handsome, warm, and imposing man of good cheer and rare intelligence, Tony made a big impression on me those several decades ago that has only grown since. I've eagerly anticipated each of his books, and never been disappointed-except in one selfish respect: I've always wanted even more of the man himself-his personal take, his lyric reflections on his subject - than the strictures of the books have allowed. Now, in The House of Owls, this is what we get, yet with no loss to the factual basis of the text. The art and the science are mutually reinforcing, as Nabokov (another fine artist and scientist in the same person) expressed when he asked: "Does there not exist a high ridge where the mountainside of scientific knowledge meets the opposite slope of artistic imagination?" That's just where we find ourselves in The House of Owls.

All this talk of artistic imagination brings us at last to the aspect of Tony's work that may be dearest to him: his graphic art. Tony is highly regarded as one of the foremost sculptors of birds and mammals, in stone, bronze, and other media. I've long thrilled to his otters, alcids, and other animals that one encounters in public places around the Pacific Northwest and beyond. But he is also immensely skilled in two dimensions. Many of his adherents acquire his books as much or more for the drawings they include as for their scientific and literary content. The House of Owls furnishes a beautiful blend of both. Interleaved among these illuminating pages you will find nearly a hundred exquisite drawings of owls in every posture, act, and attitude you can imagine. As Tony says, these drawings "are personal interpretations ... based on direct and intimate observations." Clearly he values Nabokov's high ridge and is aiming right at it, for he intends the book to "build a bridge between those who want to observe owls and the subjects themselves, because I want to convey 
how we can feel about them as well as watch them." And he hopes through this approach to inspire readers so that "the observer of owls [will] become a student and steward of them as well." I believe they will, and I am certain that every lover of Tony Angell's art will exult in this new gallery. No other birds, by a long shot, have such expressive faces, and Tony captures these in his drawings with uncanny felicity and grace, showing us their true charisma, emotion, and range of personality.

I've always been a lover of owls. Now, a very long time and many miles away from Hooty the Owl, I feel at last as though I have a place to go to fully indulge this passion. Of course, the best place is out there, in the night, among the owls themselves. But when I can't do that-or maybe afterward, by the fireside-when I hanker to learn more about the birds, relive them through splendid portraits of words and ink, maybe plan the next outing, all this in the good company of my old friend Tony-I shall betake myself to The House of Owls, and walk in. 
This page intentionally left blank 